Note

\title{
Distribution of Ascorbate Oxidase in Citrus Fruits
}

\author{
Nazamid bin SaArI, ${ }^{*}$ Shuji FuJita, ${ }^{1}$ Seiji YamaguchI ${ }^{2}$ and Tetsuzo TONO ${ }^{3}$ \\ ${ }^{1}$ Laboratory of Food Science, Faculty of Agriculture, Saga University, Saga 840, Japan \\ ${ }^{2}$ Saga University Farm, Kubo-izumi, Saga 849, Japan \\ ${ }^{3}$ Department of Food Science and Nutrition, Nishikyushu University, Kanzaki, Saga 842, Japan
}

Received November 24, 1995

\begin{abstract}
Twenty cultivars of citrus fruit were harvested at two stages of development: young fruit (weight about $2.5 \mathrm{~g}$ per fruit) and fully ripe fruit of which the ascorbate oxidase (AAO) activities were determined. Among the different cultivars, the specific activity of AAO in the young fruits ranged from 47 to 2120 units per mg protein, while fully ripe fruits had AAO specific activity ranging from 18 to 97 units per $\mathrm{mg}$ protein. Significant differences were also observed between tissue types in the AAO specific activity with the highest activity in the albedo (64-70\%), followed by the flavedo (26-34\%) and the pulp (2-3\%). Further examination of the seasonal changes in AAO specific activity in the peel (flavedo and albedo) of Satsuma mandarin fruit indicated the highest AAO activity when a fruit weight was between 2-4 g. The AAO activity then decreased as the fruit became more mature. Similar changes in the pattern of AAO specific activity were also observed for the different harvest years 1994 and 1995.
\end{abstract}

Keywords: ascorbate oxidase, ascorbic acid, citrus fruit, distribution

Ascorbate oxidase (AAO, EC 1.10.3.3) is a well known enzyme which catalyzes aerobic oxidation of $\mathrm{L}$-ascorbic acid (AsA) to dehydroascorbic acid. The enzyme was isolated from cucurbits vegetables such as zucchini squash (Dunn et al., 1951; Tokuyama et al., 1965; Lee \& Dawson, 1973; Marchesini \& Kroneck, 1979; Avigliano et al., 1983) and cucumber (Nakamura et al., 1968; Aikazyan \& Nalbandyan, 1979; Sekiya et al., 1990). Recently, the cucumber AAO has been used as an analytical tool in the enzymatic method for AsA determination. In a previous paper (Saari et al., 1995), we reported the determination of AsA by Satsuma mandarin AAO. In addition to the vegetables, there is a possibility that other citrus fruits might also serve as a good source of AAO. Because very few studies have been conducted on the occurrence and characterization of AAO from other citrus fruits except for Satsuma mandarin (Tono et al., 1985), Shamouti (Kanner et al., 1981) and Pineapple (Vines \& Oberbacher, 1963) oranges, this work attempted to examine the distribution of AAO activity in various fruit cultivars.

\section{Materials and Methods}

Citrus fruit Twenty cultivars of citrus fruits were collected from the experimental orchard of Saga University at two stages: young fruit (mid-June, weight about $2.5 \mathrm{~g}$ per fruit) and fully ripe fruit (October-November). The fruits harvested were named according to Tanaka's system (1948): Clementine (Citrus reticulata), Ponkan (Citrus reticulata), Shiikwasha (Citrus depressa), Satsuma mandarin (Citrus unshiu), Hanayu (Citrus hanaju), Hyuganatsu (Citrus Tamurana), Miyauchi-iyo (Citrus iyo), Funadoko (Citrus funadoko), Yoshida navel orange (Citrus sinensis), Valencia

* Present address: Faculty of Food Science and Biotechnology, University of Agriculture Malaysia, 43400 Serdand, Selangor Darul Ehsan, Malaysia. orange (Citrus sinensis), sour orange (Citrus aurantium), Sanbokan (Citrus sulcata), Beni-amanatsu (Citrus natsudaidai), Beni-hassaku (Citrus hassaku), Asahikan (Citrus asahikan), grapefruit (Citrus paradisi), Tosa-buntan (Citrus grandis), Meyer lemon (Citrus meyerii), lemon (Citrus limon), and Tahiti lime (Citrus aurantifolia).

Acetone powder preparation and enzyme extraction Fruits were prepared as acetone powders by blending $25 \mathrm{~g}$ of frozen tissues with about $100 \mathrm{ml}$ of ice cold acetone and filtered under suction. The residues were washed repeatedly with the cold acetone. The acetone powders were dried at ambient temperature to remove residual acetone and stored at $-20^{\circ} \mathrm{C}$ prior to use. AAOs were extracted by agitating 0.05 $\mathrm{g}$ of acetone powders with $25 \mathrm{ml}$ of McIlvaine buffer ( $\mathrm{pH} 7.0$ ) at $4{ }^{\circ} \mathrm{C}$ for $30 \mathrm{~min}$. The slurries were filtered through Toyo No. 2 filter paper (Advantec Toyo Co., Tokyo) and centrifuged at $15,500 \times g$ for $20 \mathrm{~min}$ at $0-4^{\circ} \mathrm{C}$. The resulting supernatants were used as the enzyme solution.

$A A O$ activity and protein assay AAO activity was measured by the spectrophotometric method of Tono \& Fujita (1982) summarized as follows: The assay mixture contained $0.5 \mathrm{ml}$ of $0.8 \mathrm{mM}$ ascorbic acid in $2 \%$ metaphosphoric acid $\left(\mathrm{HPO}_{3}\right)$ and $1.0 \mathrm{ml}$ of $\mathrm{AAO}$ solution. After incubation at $35^{\circ} \mathrm{C}$ for $5 \mathrm{~min}$, the reaction was stopped by adding $3.5 \mathrm{ml}$ of $2 \% \mathrm{HPO}_{3}$. One unit of AAO activity was defined as that causing an increase of 0.01 in absorbancy per min at $243 \mathrm{~nm}$. Protein was assayed by Hartree's method (1972) with bovine serum albumin as the standard.

\section{Results and Discussion}

Comparative studies of $A A O$ activity in various citrus fruit The twenty cultivars of citrus fruit analyzed in this study are either commercial citrus or used as genetic resources 


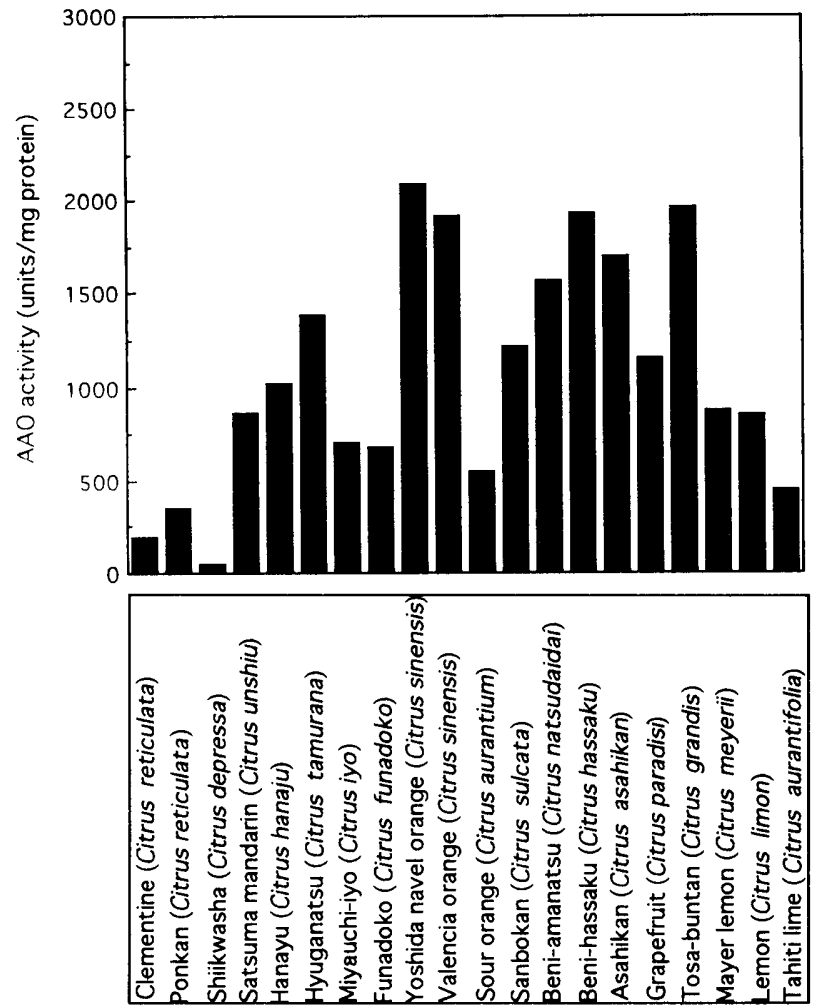

Fig. 1. Comparison of AAO specific activity in young fruit of citrus cultivars The fruits were prepared as acetone powders and the activities were measured as described in Materials and Methods. AAO activity was expressed as specific activity.

in Japan. A comparison of AAO specific activity in the young fruit of various citrus cultivars is given in Fig. 1. The results showed that the specific activity of AAO of the different cultivars varied widely from 47 to 2120 units per mg protein. The relatively higher specific activity (1570-2120 units per mg protein) was observed in the cultivars of Yoshida navel orange, Valencia orange, Beni-amanatsu, Beni-hassaku, Asahikan and Tosa-buntan, while the cultivars of Clementine, Ponkan, Shiikwasha, sour orange and Tahiti lime had a relatively low AAO activity with values of about $1 / 3$ or less of the highest range. Satsuma mandarin as well as other citrus fruits had a fairly strong AAO activity.

Figure 2 shows a comparison of AAO specific activity in the fully ripe stage of various citrus fruits. All the ripe citrus fruits examined showed variations in AAO activity ranging between 18-97 units per mg protein. The cultivars of sour orange, Sanbokan, Beni-amanatsu, lemon and Tahiti lime showed a relatively high AAO activity $(80-100$ units per mg protein). The lowest range of AAO activity was observed in the cultivars of Satsuma mandarin, Hanayu, Miyauchi-iyo, Beni-hassaku, Asahikan and grapefruit, which had a specific activity between $1 / 5-1 / 4$ of the highest $\mathrm{AAO}$ range. Other citrus fruits had AAO activity in the middle of both ranges.

It is obvious from these results that there was no consistent pattern of differences in the AAO specific activity between the two stages even though the AAO specific activity of all the young citrus fruits contained much greater concentration levels (4-90 times) than the fully ripe fruit except for Shiikwasha which showed no difference in AAO activity.

In order to determine the AAO activity content in the
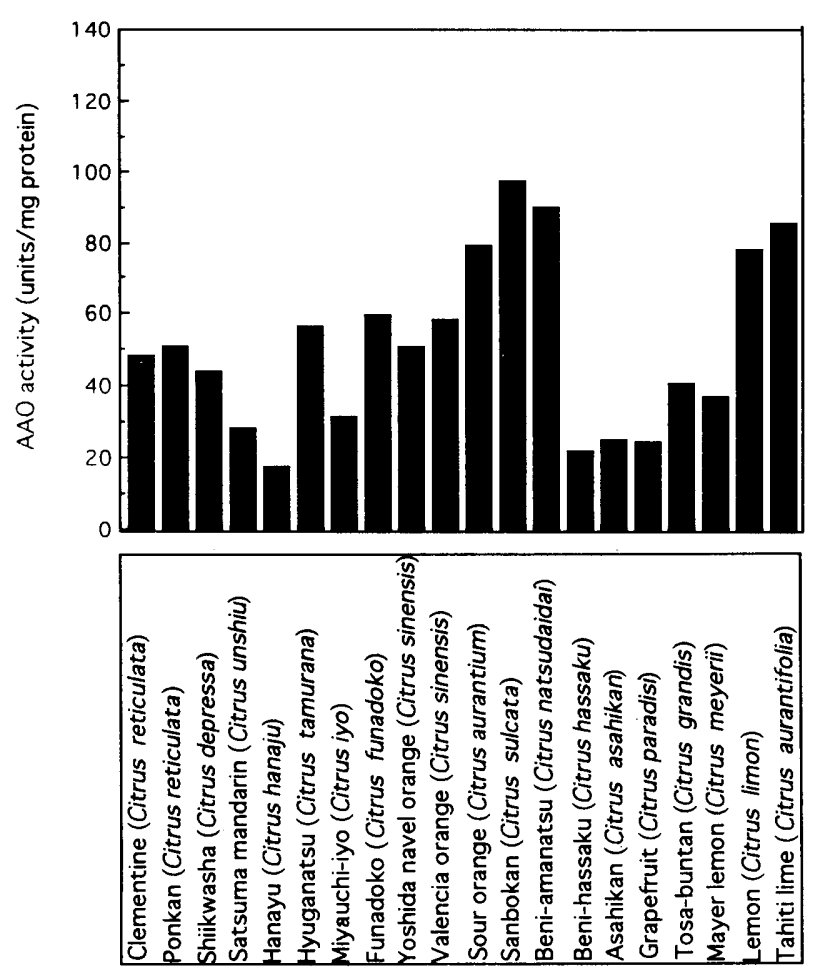

Fig. 2. Comparison of AAO specific activity in fully ripe fruit of citrus cultivars. The fruits were prepared as acetone powders and the activities were measured as described in Materials and Methods. AAO activity was expressed as specific activity.

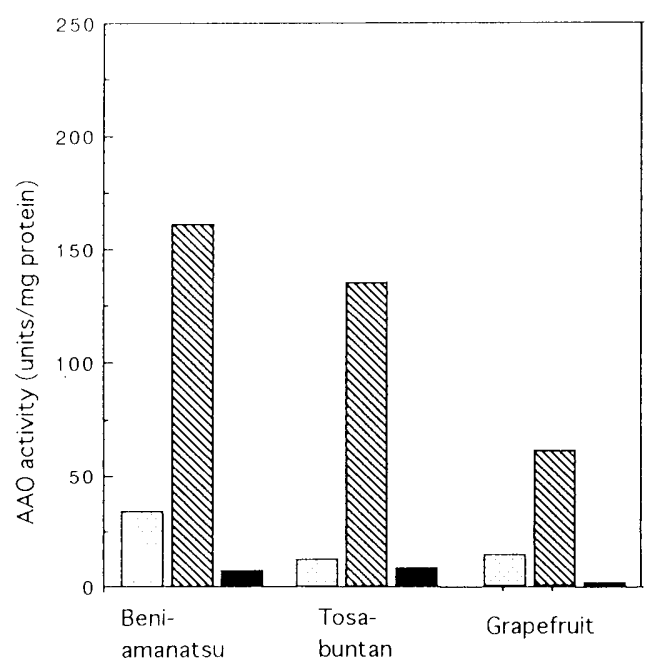

Fig. 3. Comparison of $\mathrm{AAO}$ activity in various parts of fully ripe citrus fruits. Flavedo $(\hat{j})$, albedo $\left(\aleph^{5}\right)$ and pulp $(\boldsymbol{\square})$ were removed from each of the fruits. The tissues were prepared as acetone powders as described in Materials and Methods. AAO activity was expressed as specific activity.

component parts of citrus fruit, Beni-amanatsu, Tosa-buntan and grapefruit were selected, each of the fruits was separated into flavedo, albedo and pulp tissues, and their AAO specific activities were determined. As shown in Fig. 3, significant differences were seen between tissue types in the content of AAO activity. The highest AAO content was observed in the albedo (64-70\%), followed by flavedo (26-34\%) and the pulp $(2-3 \%)$ in all the fruits examined. This is in contrast with the result reported by Nagy (1980) who observed higher concentration of AAO in the flavedo than in any other parts of citrus 


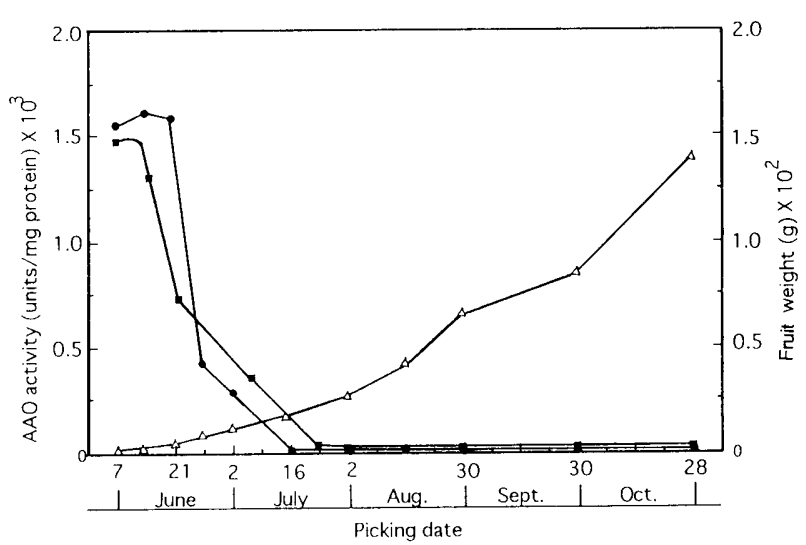

Fig. 4. Changes in AAO activity in the peel (flavedo and albedo) of Satsuma mandarin fruit during development. Random sampling was carried out every 7-14 days from selected trees starting with the early development stage (early June) to the fully ripe stage (end of October). Each sample was brought to the laboratory immediately after harvest and then peeled. One hundred grams of the peel were blended with 1.5 volume of its weight of $0.1 \mathrm{M}$ phosphate buffer $\mathrm{pH} 7.0$, containing $2 \%$ polyvinylpolypyrrolidone (Sigma Chem. Co., St. Louis. USA) as a phenolic scavenger for $2 \mathrm{~min}$. The slurries were filtered through cotton cloth, and the supernatants were centrifuged at $15,500 \times \mathrm{g}$ for $30 \mathrm{~min}$ at $1-4^{\circ} \mathrm{C}$. Protein precipitated between 0-80\% saturation was used as the enzyme solution. Activities of AAO were assayed as described in Materials and Methods in triplicate. AAO activity for the fruit harvested in $1994(\bullet)$ and 1995 $(\boldsymbol{\square})$, average wet weight of the fruit $(\triangle)$.

fruit. Because the relative quantities in the component parts of each citrus fruit may differ considerably from fruit to fruit, the higher proportions of albedo than that of flavedo in the fruit tested could be the reason for high levels of AAO activity.

The changes in AAO activity in Satsuma mandarin fruit Satsuma mandarin is the most abundant cultivar of the fruit of the genus Citrus in Japan (Nagy, 1980). Based on the above results, the seasonal changes in AAO activity in the peel (albedo and flavedo) of Satsuma mandarin harvested from early June to end of October was examined. The average wet weight of the fruit increased in a sigmoidal manner (Fig. 4). The specific activity of AAO decreased as the fruits became more mature. It was highest in the early June when the fruit weight was between 2 to $4 \mathrm{~g}$. As the weight per fruit increased, a sudden fall in AAO activity was observed. A remaining specific activity of about $1 / 90$ of the specific activity in the early stage was observed as the fruits reached maturity with an average weight (wet basis) of about $9 \mathrm{~g}$ per fruit. Thereafter, the specific activity remained essentially the same.

The effect of a different harvest year (1995) on the AAO activity profile during development was also investigated. Similar changes in the pattern of AAO activity were observed.

From these results, a correlation of high AAO specific activity with high growth rate in Satsuma mandarin fruit seemed to exist. The peaking of protein contents expressed in terms of specific activity at the early stage indicated the most active growing period during which AAO could have been involved with growth processes in the dividing cells (Lin \&
Varner, 1991). This is in agreement with results reported by many researchers (Nagy, 1980; Tono et al., 1985; Lin \& Varner, 1991).

It is obvious from the above results that factors such as variety and maturity play an important role in determining the activity of AAO in citrus fruit, in addition to other factors such as climate, horticultural practice, and storage conditions. From these results, with the trend of increasing demand for $\mathrm{AAO}$ as a diagnostic reagent for the determination of vitamin $\mathrm{C}$, the high concentrations of AAO activity in certain young citrus fruits especially the fruit Satsuma mandarin, may represent a potential source of the enzyme.

\section{References}

Aikazyan, V.T. and Nalbandyan, R.M. (1979). Copper-containing proteins from Cucurmis sativus. FEBS Lett., 104, 127-130.

Avigliano, L., Vecchini, P., Sirianni, P., Marcossi, G., Marchesini, A. and Mondovi, B. (1983). A reinvestigation on the quaternary structure of ascorbate oxidase from Cucurbitaceae pepo medullosa. Mol. Cell. Biochem., 56, 107-112.

Dunn, F.J., Dawson, C.R. and Lewis, S. (1951). The nature of ascorbic acid oxidase. J. Biol. Chem., 189, 485-497.

Hartree, E.F. (1972). Determination of protein: A modification of Lowry that gives a linear photometric response. Anal. Biochem., 48 , 422-427.

Kanner, J., Harel, S. and Ben-Shalom, N. (1981). Ascorbate oxidase in mature orange peel. J. Food Sci., 46, 1407-1409.

Lee, M.H. and Dawson, C.R. (1973). Ascorbate oxidase: Further studies on the purification of the enzyme. J. Biol. Chem., 248, 65966602.

Lin, L.S. and Varner, J.E. (1991). Expression of ascorbic acid oxidase in zucchini squash (Cucurbita pepo L.). Plant Physiol., 96, 159-165.

Marchesini, A. and Kroneck, M.H. (1979). Ascorbate oxidase from Cucurbita pepo medullosa: New method of purification and reinvestigation of properties. Eur. J. Biochem., 101, 65-76.

Nagy, S. (1980). Vitamin C contents of citrus fruit and their products: A review. J. Agric. Food Chem., 28, 8-18.

Nakamura, T., Makino, M. and Ogura, Y. (1968). Purification and properties of ascorbate oxidase from cucumber. J. Biochem., 64, $189-195$.

Saari, N.B., Fujita, S., Miyazoe, R., Haraguchi, K. and Tono, T. (1995). Prospect of using ascorbate oxidase from satsuma mandarin (Citrus unshiu Marc.) for ascorbic acid determination by the difference spectra method. Food Sci. Technol., Int., 1, 22-25.

Sekiya, J., Hamade, R., Kimura, O., Mizuno, K. and Shimose, N. (1990). Purification and properties of ascorbate oxidase from cucumber fruit. Soil Sci. Plant Nutr., 36, 1-7.

Tanaka, Y. (1948). "An Iconograph of Japanese Citrus Fruits. A Monographic Study of Species and Varieties of Citrus Fruits Grown in Japan." Yokendo Co., Ltd., Tokyo, Japan, 2 vol.

Tokuyama, K., Clark, E.E. and Dawson, C.R. (1965). Ascorbate oxidase: A new method of purification. Characterization of the purified enzyme. Biochemistry, 4, 1362-1370.

Tono, T. and Fujita, S. (1982). Spectrophotometric determination based on difference spectra of L-ascorbic acid in plant and animal foods. Agric. Biol. Chem., 46, 2953-2959.

Tono, T., Fujita, S. and Kawasaki, H. (1985). Ascorbate oxidase in soluble solid from satsuma mandarin peel and determination of its activity during the fruit development. Nippon Shokuhin Kogyo Gakkaishi, 32, 738-745 (in Japanese).

Vines, H.M. and Oberbacher, M.H. (1963). Citrus fruit enzyme 1. Ascorbic acid oxidase in oranges. Plant Physiol., 38, 333-337. 